\title{
INDIKATOR PENYUSUTAN SUMBER DAYA IKAN PELAGIS KECIL DI LAUT JAWA DAN SEKITARNYA
}

\author{
Suherman Banon Atmaja" dan Duto Nugroho") \\ 'Peneliti pada Balai Riset Perikanan Laut, Muara Baru-Jakarta \\ ") Peneliti pada Pusat Riset Perikanan Tangkap. Ancol-Jakarta
}

\begin{abstract}
ABSTRAK
Sumber daya ikan pelagis telah lama dieksploitasi oleh berbagai macam alat mulai dari alat tangkap payang, pukat cincin, pukat cincin yang dilengkapi dengan lampu sorot. Motorisasi perikanan tradisional dan substitusi alat tangkap telah menyebabkan crowding effect. Status perikanan pelagis kecil telah melampaui MYS. Semakin berkembangnya pukat cincin dengan penggunaan lampu sorot dan mesin yang lebih besar, sejak tahun 1998 pengusaha pukat cincin cenderung mengurangi kapasitas kapal, namun penggunaan lampu sorot semakin meningkat. Dengan demikian, waktu pencarian gerombolan ikan lebih lama, sebagai indikator biomassa telah mengalami penyusutan. Telah terjadi kompetisi spesies ikan pelagis, penurunan hasil tangkapan terhadap populasi ikan akan direspon dengan cepat pulihnya biomassa ikan pelagis kecil dan nelayan akan merespon perubahan alat tangkap. Perlu kehati-hatian dalam memberikan perizinan, harus memperhitungkan dinamika usaha perikanan yaitu bagaimana nelayan akan merespon kondisi stok yang menurun.
\end{abstract}

KATA KUNCl: penangkapan, sumber daya ikan, pelagis kecll, Laut Jawa

\section{PENDAHULUAN}

Sumber daya ikan pelagis telah lama dieksploitasi oleh berbagai alat tangkap, salah satunya adalah payang. Payang (danish seine) telah beroperasi di dekat pantai utara Laut Jawa dari Kepulauan Seribu (Jakarta) sampai dengan Kepulauan Kangean di bagian timur Laut Jawa (Rossedaal, 1910). Verloop (1904) mengatakan hasil tangkapan payang yang didaratkan di sepanjang pantai utara Jawa mencapai sekitar 28.000 ton. Pada 1909, hasil tangakap alat ini di sekitar Kepulauan Kangean sekitar 9.000 ton, terutama jenis ikan layang (Decapterus spp.) (Kampen, 1922). Sejak 1970-an, perkembangan eksploitasi sumber daya ikan pelagis kecil di Laut Jawa sangat erat kaitannya dengan perkembangan alat tangkap pukat cincin. Setelah pasca pelarangan pukat harimau (1980), alat tangkap ini menjadi semi industri dan berkembang cepat, baik kapasitas penangkapan (ukuran kapal dan termasuk kekuatan mesinnya) dan perluasan daerah penangkapan, maupun peningkatan efisiensi penangkapan melalui penggunaan jumlah lampu sorot (cahaya) yang cenderung meningkat.

Hampir sebagian besar usaha perikanan tangkap di Indonesia mempunyai karakteristik akses terbuka tanpa pembatasan upaya penangkapan, kompetisi bebas terjadi antara perikanan skala besar dan kecil. Dengan kerangka acuan pengelolaan sumber daya ikan berdasarkan pada target titik acuan kriteria maksimum atau opitimasi dari (maximum sustainable yield) disebut juga target reference point. Sebelum mencapai tingkat maximum sustainable yield, kebijakan menambah akan terus dilakukan tanpa memperhatikan dinamika perikanan yang terjadi. Keberhasilan motorisasi perikanan tradisional telah menyebabkan crowding effect di wilayah pesisir utara Pulau Jawa dan substistusi alat tangkap sebagai respons turunnya stok ikan. Sejumlah kapal pukat cincin telah berubah menjadi cantrang untuk ikan demersal dan kapal rawai dasar diubah menjadi cantrang dan stick held dipnet untuk cumi-cumi. Substitusi alat tangkap tersebut merupakan bagian dari nelayan dalam mempertahankan kelangsungan hidupnya.

Status perikanan pelagis kecil melalui cara plot tumpah tindih kurva pertumbuhan bersih dan hubungan biomasa hasil tangkapan menunjukkan bahwa hasil tangkapan telah berada sebelah kiri $B_{\text {MSY }}$ (tingkat eksploitasi telah melampaui maximum sustainable yield), titik di mana pertumbuhan bersih adalah maksimum. Pada situasi tingkat tersebut biomassa ikan pelagis telah menyusut lebih dari setengah dari biomassa awal (Atmaja \& Nurhakim, 2005)

Pada kondisi besaran stok ikan telah menyusut. penambahan kapal baru memasuki usaha perikanan maka nelayan atau pengusaha cenderung akan meningkat kemampuan penangkapan ikan dengan perbaikan dan inovasi teknologi yang lebih maju, terutama penggunaan jumlah lampu sorot cenderung meningkat terus tanpa kendali dan akhir-akhir ini telah dimulai penggunaan lampu di bawah air (under water lamp). Peningkatan efisiensi penangkapan tersebut akan meningkatkan keberhasilan hasil tangkapan dari individu kapal yang bersifat sementara, karena setiap keberhasilan (laba) akan menarik dan diikuti oleh nelayan lainnya.

\section{INDIKATOR PENANGKAPAN}

Sejak alat tangkap pukat cincin diperkenalkan tahun 1970-an, alat ini berkembang terus dengan 
pesat menggantikan alat tangkap tradisional payang. Perkembangan usaha perikanan pukat cincin di Laut Jawa dapat dikelompokan menjadi 4 periode, yaitu periode tahun 1976 sampai dengan 1981 (sebelum pelarangan alat tangkap trawl, sebagian besar mereka beroperasi di daerah penangkapan tradisional, rata-rata kekuatan propulsi mesin sekitar $120 \mathrm{PK}$, panjang jaring berkisar 200 sampai dengan $400 \mathrm{~m}$, dan taktik penangkapan menggunakan rumpon ditanam di laut), periode tahun 1982 sampai dengan 1984 (rata-rata kekuatan propulsi mesin berkisar 150 sampai dengan $165 \mathrm{PK}$, panjang jaring berkisar 200 sampai dengan $600 \mathrm{~m}$, dan mereka sudah memperluas daerah operasi ke bagian timur Laut Jawa dan Selat Makassar, taktik penangkapan sebagian kapal telah menggunakan lampu sorot (ratarata 3.100 watt) sebagai alat bantu utama menggantikan rumpon). Periode tahun 1985 sampai dengan 1990 (kekuatan propulsi mesin berkisar 120 sampai dengan $330 \mathrm{PK}$, panjang jaring berkisar 400 sampai dengan $750 \mathrm{~m}$, dan lampu sorot halogen dan mercury rata-rata 5.100. Periode tahun 1991 sampai dengan 2001, penggunaan lampu sorot meningkat menjadi 7.500 watt sampai dengan 20.000 watt. Kekuatan propulsi mesin meningkat dari 120 PK menjadi 330 PK (Gambar 1). Sejak tahun 1998 pengusaha perikanan pukat cincin kecenderungan mengurangi volume palka (kapasitas kapal), jumlah lampu semakin banyak dari 21 lampu menjadi 25 lampu (dari daya 16.000 watt menjadi 20.000 watt). Dengan demikian, penggunaan jumlah lampu sorot cenderung meningkat terus tanpa kendali, sedangkan perluasan daerah penangkapan didukung dengan pemberian izin (surat izin penangkapan ikan), di mana perikanan pukat cincin skala besar dapat beroperasi di 3 wilayah pengelolaan perikanan (Laut Jawa, Laut Cina Selatan, dan Selat Makassar dan Laut Flores). Sedangkan pada perikanan pukat cincin mini didukung hubungan tradisional yang dikenal dengan andon, sehingga mobilisasi perikanan pukat cincin mini terjadi di perairan pesisir utara Laut Jawa dan selatan Kalimatan.

Sebaliknya, aktivitas penangkapan armada pukat cincin cenderung menurun, terutama jumlah trip dan rata trip atau kapal, sedangkan jumlah hari operasi meningkat terus. Hal ini, mempunyai arti bahwa waktu untuk pencarian gerombolan lebih lama, sebagai indikator biomassa telah mengalami penyusutan. Nelayan semakin lama tinggal di laut untuk memperoleh hasil tangkapan yang memadai atau pemilik atau nakhoda kapal lebih berorientasi terhadap keberhasilan setiap tripnya. Penurunan jumlah trip dapat diartikan juga semakin banyak kapal yang tidak melaut (hanya bertambat di pelabuhan) (Atmaja et al., 2002). Sebagai contoh yang diwakili

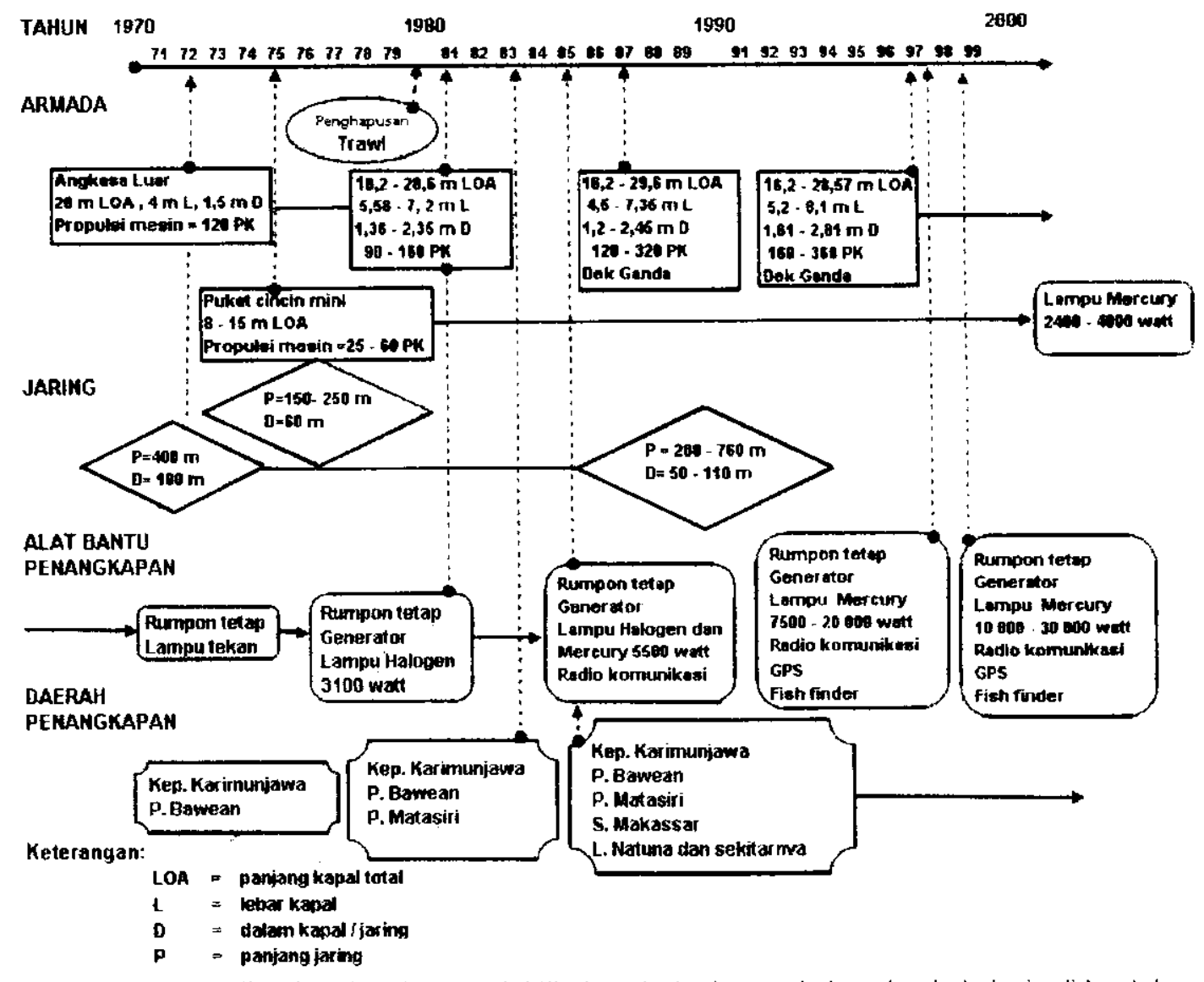

Gambar 1. Periodisasi perkembangan taktik dan strategi armada kapal pukat cincin di Laut Jawa. 
oleh kelompok usaha perikanan Margo, pelopor menggunakan alat bantu pengumpul ikan lampu sorot (cahaya) menggantikan peranan rumpon dan penggunakan kapasitas kapal yang lebih besar (ukuran kapal>100 GT dan kekuatan mesin>300 PK). Selain itu, kelompok ini juga mendapat bantuan teknik perbaikan (peningkatan kualitas ikan dengan penanganan hasil tangkapan dengan menggunakan es curah (flake ice), penggunaan sistem penentuan posisi (GPS), peningkatan teknik penangkapan dengan rancang bangun jaring dan operasi penangkapan) yang diperkenalkan lewat Proyek Java Sea Pelagic Fisheries Assessment.

Keberhasilan kompetisi pada awal penggunaan lampu sorot dan ditunjang dengan kemampuan kapal untuk memperluas dan pencarian daerah penangkapan baru merupakan faktor utama kesuksesan usaha perikanan kelompok Margo. Namun demikian, kenaikan biaya operasional sejak tahun 1998 akibat resesi ekonomi dan kebijakan pemerintah mengurangi subsidi bahan bakar minyak pada tahun 2000 telah melambungkan biaya operasional bagi kapal yang berkapasitas besar, sedangkan hasil tangkapan yang diperoleh tidak cukup menutupi biaya operasional. Nelayan tidak memperoleh bagian dari hasil lelang dan nelayan meninggalkan sebagai $A B K$ kapal, sehingga sebagian kapal mereka hanya bertambat di pelahuhan. Pada tahun 1997 atau 1998 jumlah kapal kelompok Margo yang aktif 22 kapal, tahun 2002 sekitar 17 kapal yang aktif (5 kapal telah dijual), tahun 2003 hanya 10 kapal yang aktif dengan rata-rata 5,1 trip per kapal dan selama tahun 2004 hanya sekitar 6 kapal yang aktif dengan rata-rata 3 trip per kapal. Hal ini, menunjukkan bahwa jika nilai hasil tangkapan berkurang dibandingkan dengan biaya eksploitasi dan beban biaya kerja yang harus ditanggung semakin besar, maka beberapa pengusaha akan keluar dari usaha perikanan. Sejumlah kapal pukat cincin dari perusahaan berbeda lebih berani dengan memindahkan daerah penangkapan ke Laut Sulawesi dan Teluk Tomini untuk mengeksploitasi sumber daya laut dalam, dengan menambah penggunaan lampu di bawah air (under water lamp) dan modifikasi kedalaman jaring

\section{INDIKATOR BIOLOG|}

Sumber daya ikan pelagis di Laut Jawa terdiri atas komunitas ikan pelagis pantai (Sardinella spp., Rastrelliger brachysoma, Dusumieria acuta, dan Selar spp.), ikan pelagis neritik dan oseanik (Decapterus russelli, Selar crumenophthalmus, Rastrelliger kanagurta, Decapterus macrosoma, Amblygaster sirm, Megalaspis cordyla, Scombemorus spp., dan Auxis thazard). Kelompok jenis ikan layang (Decapterus spp.) merupakan komponen utama di perairan ini, dominasi jenis ikan ini terjadi pada daerah penangkapan yang dipengaruhi oleh massa air bersifat oseanik. Keberadaan dan dominasi kelompok jenis ikan layang (Decapterus spp.) sebagai tujuan penangkapan sangat menentukan pola aktivitas penangkapan armada pukat cincin.

Komunitas ikan mendiami suatu karakteristik ekosistem yang dikontrol oleh kaidah biofisik, di sana hidup berdampingan pemangsa alami (predator) dengan mangsa (prey). Dengan pandangan sederhana bahwa nelayan sebagai pemangsa baru yang memasuki sistem tersebut, dan dalam konteks perikanan multispecies, nelayan sebetulnya adalah pemangsa jenis lain. Sampai dengan batas tertentu (hasil tangkapan lestari), jumlah ikan yang tertangkap oleh nelayan menggantikan kematian alami. Tetapi di luar batas tersebut, eksploitasi akan menurunkan populasi ikan, pada gilirnya kekosongan niche ekologi dari penurunan 1 spesies kerapkali digantikan sementara oleh spesies lainnya (Laevastu \& Favorite, 1988). Pauly (1982) diacu dalam Seijo et al. (1998) mengatakan lebih tangkap (over fishing) yang telah diamati adalah kecenderungan menurunnya sebagian besar komunitas ikan tingkat tinggi dari tropic chain. Pauly (1982) diacu dalam Martosubroto (1982) mengatakan bahwa spesies sebagai mangsa (prey) akan mengalami penurunan lebih dahulu, selanjutnya diikuti oleh spesies sebagai pemangsa (predator).

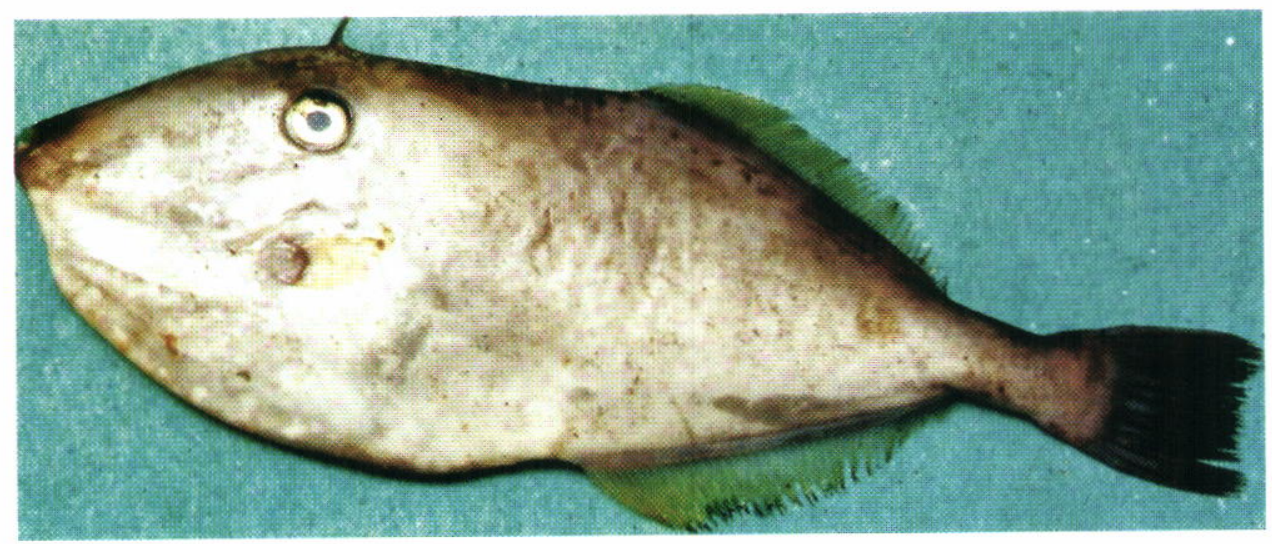

Gambar 2. Ikan ayam-ayaman (leather jacket, Alesterus monoceros). 
Dinamika biomassa secara matematika yang mengggambarkan bagaimana pengaruh hasi tangkapan terhadap populasi ikan menunjukkan bahwa penurunan hasil tangkapan akan direspon dengan cepat pulihnya biomassa ikan pelagis kecil (Atmaja, 2005). Sedangkan secara biomatematika boleh jadi pulihnya stok ikan adalah palsu (quasi recovery) karena telah terjadi kompetisi spesies ikan pelagis (interspesific competition) ditunjukan oleh perubahan komposisi hasil tangkapan, di daerah penangkapan bagian timur Laut Jawa selama 3 tahun terakhir ini. Kejadian melimpahnya hasil tangkapan ikan ayam-ayaman (leather jacket, Alesterus monoceros), (Gambar 2) mencapai $43 \%$ dari total hasil tangkapan ketika puncak musim ikan layang atau adanya perubahan sasaran ikan yang menjadi tujuan akibat sudah terbatasnya stok ikan layang Alterasi spesies umum terjadi pada perikanan multispesies Sebagaimana teiah diketahui bahwa pada perikanan tropis, perikanan mengeksploitasi lebih dari 1 stok ikan yang mempunyai berbagai trophic levels. Kekosongan niche ekologi dari penurunan 1 spesies kerapkali digantikan sementara oleh spesies lainnya (Atmaja et al., 2003). Situasi tersebut menunjukkan bahwa sumber daya perikanan adalah sumber daya yang dinamis dan masuk keluarnya upaya penangkapan pada usaha perikanan tidak bersifat statis.

\section{IMPLIKASI PENGELOLAAN}

Dua masalah utama pada perikanan tangkap di Laut Jawa, yaitu pertama subsektor perikanan menjadi salah satu tumpuan lapangan kerja bagi penduduk yang tidak mampu bersaing pada sektor lapangan kerja lain, terutama di wilayah pesisir sebagai konsekuensi peningkatan penduduk. Berdasarkan pada statistik Propinsi Jawa Tengah selama periode tahun 1997 sampai dengan 2001, keikutsertaan rumah tangga perikanan dan perusahaan perikanan meningkat mencapai $31 \%$, sedangkan perahu motor tempel dan kapal motor meningkat masing-masing 26 dan 69\%. Pada kondisi sumber daya ikan yang semakin terbatas, sedangkan tanpa pembatasan keikutsertaan dalam usaha perikanan dan kecenderungan hasil tangkapan yang semakin menurun, serta biaya eksploitasi yang meningkat. Suatu hal yang tidak mengherankan kita akan mengenal istilah winner and losser, di mana sebagian kapal lama akan kalah bersaing dalam perebutan gelombolan ikan, karena kapal baru telah meningkatkan kemampuan menangkap ikan dengan perlengkapan teknologi yang lebih maju. Oleh karena itu, beberapa pengusaha akan keluar dari usaha penangkapan atau mencari alternatif baru dengan mengganti alat tangkap. Dari sudut pandang Pemerintah Daerah adalah memaksimumkan kesempatan kerja bagi penduduknya, sehingga perubahan alat tangkap tidak diatur secara ketat agar tidak terjadi banyak pengangguran.
Kedua pendugaan stok ikan yang bersifat statis, terkesan hanya membuat prediksi tingkat upaya penangkapan optimum dan hasil tangkapan lestari, tanpa memperhitungan dinamika usaha perikanan, yaitu bagaimana nelayan akan merespon pada kondisi stok yang telah menyusut dan perikanan dalam kondisi kritis ketika pendapatan nelayan menurun di bawah tingkat wajar, serta dampak berantainya.

\section{KESIMPULAN}

Dari uraian di atas dapat ditarik beberapa kesimpulan, sebagai berikut:

1. Dari indikator di atas, perlu pendekatan kehatihatian atau tindakan keberanian pembatasan memberikan perizinan kapal pukat cincin baru untuk beroperasi di Laut Jawa dan sekitarnya.

2. Penambahan kapal baru memasuki perikanan pada kondisi stok ikan yang sudah menurun, pengusaha cenderung meningkatkan kemampuan menangkap ikan dengan periengkapan teknologi yang lebih maju (jumlah lampu sorot dari daya 16.000 watt menjadi 20.000 watt), maka akan terjadi semakin kompetitif perebutan gerombolan ikan.

3. Sumber daya perikanan adalah merupakan sumber daya yang dinamis, yaitu stok ikan dapat bertambah dan berkurang baik secara alamiah maupun akibat eksploitasi; begitu juga masuk keluarnya upaya penangkapan dalam usaha perikanan tidak bersifat statis.

4. Pada kondisi sumber daya ikan yang sudah menurun, pengusaha merespon dengan rasionalisasi melalui pengurangan jumlah trip dan keluar dari usaha perikanan atau merubah alat tangkap yang digunakan. Pada perikanan akses terbuka dan tanpa kendali maka pengurangan subsidi pemerintah (kenaikan harga bahan bakar minyak) ternyata lebih efektif untuk pengurangan ekspansi upaya penangkapan kapal pukat cincin.

\section{DAFTAR PUSTAKA}

Atmaja, S. B \& B. Sadhotomo. 2002. Dinamika perikanan purse seine di Laut Jawa dan sekitarnya. Tesis Program Pascasarjana. Institut Pertanian Bogor. Bogor. 62 hal (tidak dipublikasikan)

Atmaja, S. B., Mahasisworo, Suwarso, \& T. Haryati. 2003. Pengkajian stok ikan di wilayah pengelolaan perikanan Laut Jawa. Prosiding Forum Pengkajian Stok Ikan Laut 2003. Pusat Riset Perikanan Tangkap. Badan Riset Kelautan dan Perikanan. Departemen Kelautan dan Perikanan. 21p 
Atmaja, S. B. \& S. Nurhakim. 2005. Pengkajian stok ikan pelagis kecil di Laut Jawa dan sekitarnya: Pendekatan dinamika perilaku biomassa.

Laevastu, T. \& F. Favorite. 1988. Fishing and stock fluktuation. Fishing New Books. England. 239 p.

Martosubroto, P. 1982. Fishery dynamics of the demersal resources of the Java Sea. Phd. Dessertation. Dalhousie University. Canada. 238 p.

Kampen van, P. N. 1922. Visscherij en vischteett in Nederlandsch indie. HD. Tjeenk Willink \& Zoon. Harlem. 106 p.

Potier, M. 1998. Pécherie de layang et senneurs semi industrie/s Javanais: Perspective historique et approche système. Phd Thesis. Université de Montpellier II. $280 \mathrm{p}$

Seijo J. C., O. Defeo, \& S. Salas. 1998. Fisheries bioeconomics: Theory, modelling, and management. FAO Fish. Tech. Paper 368. FAOUN. $108 \mathrm{p}$

Van Rosendaal, A. M. 1910. De layangvisscherij in de Java zee en in Straat Madoera. Mededelingen van het visscherij station te Batavia. Buitenzorg. $5,21-24$

Verloop, G. N. 1904. Het zeevisscherij bedrijf: Haar toestand in 1870-1902, Haar achteruitgang en middelen tot herstel. Tijdschit voor nijverheid en landbouw in Nederlandsch-Indis. 69. 27-33. 
rotis 